\title{
Role of Database Marketing in Improving Quality of Service in Jordanian Private Hospitals
}

\author{
Tareq Hashem ${ }^{1}$ \\ ${ }^{1}$ Associate professor, Marketing Department, Isra University, Amman, Jordan \\ Correspondence: Dr. Tareq Hashem, Associate professor, Marketing Department, Isra University, Amman, \\ Jordan.
}

Received: November 2, 2021

Accepted: November 22, 2021

Online Published: November 25, 2021

doi:10.5539/ibr.v15n1p26

URL: https://doi.org/10.5539/ibr.v15n1p26

\begin{abstract}
Current study aims to determine the role of database marketing in improving quality of service in Jordanian private hospitals. The study's population is consisted of marketing managers only or their deputies in the Jordanian private hospitals which contains (69) hospitals. Online questionnaire was distributed over a random sample amounting (59) managers, (51) questionnaires were collected, that is $(86.44 \%)$ of the total sample. The study results indicated that Jordanian private hospitals use database marketing in improving quality of Service in Jordanian Private Hospitals. There is no difference in the role of database marketing in improving quality of service in Jordanian private hospitals according to the managers' educational level. There is a difference in the role of database marketing in improving quality of service in Jordanian private hospitals according to the managers' experience.
\end{abstract}

Keywords: database marketing, service, quality of service, health service, Jordanian private hospitals

\section{Introduction}

Technological development is of great importance for organizations in various sectors, as it helps departments in the decision-making process, and this development increases the desired benefit of using databases in the marketing departments of these organizations. (Hashem, 2016). The use of database marketing as a marketing tool began in 1980s and continues to grow day by day. which reflects its importance in marketing field in general and direct marketing in particular (comm., 1998).

Database known as "a group, typically large, of organized data for the purpose of serving a number of applications efficiently, by storing and managing data, in order to appear in one location, thus they reduce the flood of data." (Guendhilji, and al-Janabi, 2005). The database is "a self-described group of integrated files and records " (Yassin, 2005, p. 229).

Also known as "a set of data stored in the computer and organized to meet the requirements of the user in an easy and effective, and contain the various files related to a sub-system of a particular organization or a number of integrated sub-systems. " (Hamidi et al, 2004, p. 181).

Qteishat, (2005) defined database as "a collection of information or related data, with the mutual relationship among them and stored in a professional manner without recurrence."

From marketing perspective, database marketing can be the defined as "a database that can be used to connect and direct marketing efforts, in addition to current construction of information, and to guide future efforts." (Strubel, 2000).

Database marketing is also defined as a:" collection of data, such as: customers' names, addresses and purchases, which provides marketers with information that enables them to make better working -decisions for accomplishing the company's objectives "( Schoenbachler, et al. 1997).

Tapp (2005) also defined database marketing as a "comprehensive collection of interrelated data serving multiple applications, allowing timely and accurate on- demand retrieval of relevant data, and having a data management system independent of applications"

As for (Ekman, Erixon and Thilenius, 2015), database marketing is defined as a comprehensive and integrated collection of data that is directly related to marketing through various applications and services, which are 
accurate in nature and have an independent management system.

When we talk about database we should know that data are composed of numbers, records, symbols, and the like about real things, that may be gained from two sources: One is environmental sources and the second source is the records or reports kept on the activities of the firm itself .( EREN \& ERDOGMUS, 2004)

Meanwhile, information is data that has been given meaning by way of relational connection. This "meaning" can be useful, but does not have to be. In computer parlance, a relational database makes information from the data stored within it. ( Ackoff, 1989)

In addition, the marketing database is the most important requirement in the field of e-marketing, as it is a set of procedures that are created through the data that are collected and retrieved and in its latest form capable of supporting the decision-making process within the company (Singh and Saini, 2016).

Marketing databases are among the basic tools that the marketer uses to reach customers, interact with them and know their purchasing behavior, in addition to retaining data related to them, which would support the purchasing power of the company's products and services and thus achieve a strong relationship between the company and the customer and ensure the continuity and perpetuation of this relationship (Kim et al. ., 2012).

The requirements for using database marketing can be summarized as follows:

- Availability of high moral character for the users of personal information.

- Provide work teams from different departments working effectively together in the utilization of data provided by the databases. (Brzezinski, 1999)

- Take advantage of the Internet in the development of the database marketing organization (O'Leary, et al, 2004)

Also, Pokorny (2013) indicated that the requirements of marketing databases are: the high morals enjoyed by the users of these systems. In addition, it is necessary to provide multiple and different work departments to work on these systems in order to avoid confusion between the information, and each department is responsible for the operations required of it.

Advantages of using database marketing:

- To reduce costs through the use of data provided by the databases in the investigation and activation of direct marketing. (Bean, 1997).

- To increase revenue by focusing on the preferences of customers in wide range of products (Bean, 1997).

- Provide full information for each customer. (Dawes \& Worthington, 1996)

- Take quick decisions as a result of rapid access to information availability. (Dawes \& Worthington, 1996).

- To reduce excess stocks of the product through the use of e-mail address of customers.

- The ability to arrange and organize information to contribute to the achievement of the objectives of the organization. (Parish, 1998).

- Provide information needed by marketers when they use the methods of direct marketing. (Friedman \& Giladi, 2000)

The researcher should clarify the differences between database marketing and consumer relationship marketing, because of increased uncertainty and confusion between the two concepts, which recently led to the emergence of the need to clarify the differences between them (Hashem, 2012).

Table 1 illustrates these differences:

Table 1. Differences between database marketing and relationship marketing

\begin{tabular}{|l|l|}
\hline CRM & DM \\
\hline $\begin{array}{l}\text { - Depends on the development of technology, particularly the } \\
\text { achievement of its objectives }\end{array}$ & $\begin{array}{l}\text { - Rely on existing technology with the need to adapt to their } \\
\text { objectives. }\end{array}$ \\
\hline $\begin{array}{l}\text { - Can provide information specific to each customer or } \\
\text { potential customer }\end{array}$ & $\begin{array}{l}\text { - Can identify sectors or parts of the market through the } \\
\text { reaction of the consumer. }\end{array}$ \\
\hline $\begin{array}{l}\text { - Depends on creating personal relationships with customers } \\
\text { and to contribute to the activation of responses. }\end{array}$ & $\begin{array}{l}\text { - Expects consumer behavior and constantly acting on his } \\
\text { behavior. }\end{array}$ \\
\hline - It is assumed that the consumer needs to a relationship with & - building relationships with the consumer when he was in \\
\hline
\end{tabular}


\begin{tabular}{|l|l}
\hline the company. & point of sale.
\end{tabular}

\begin{tabular}{l|l} 
- Needs to be a year to design and start work. & - Needs to 4-6 months to start providing the information.
\end{tabular}

(Mckim, 2002)

Hence, any organization uses these databases should focus on the provision of the following:

- $\quad$ Clarify the date of the latest purchase of the consumer.

- $\quad$ The size and the number of times of purchase.

- $\quad$ Thanking the consumer after each purchase.

- $\quad$ Send some gifts for customers with loyalty to the company.

- Provision of data through external sources.

- Storage of detailed data about the marketing campaigns of the organization. (Klopp,2000,B.G,1998,Parish,1998,Kahan,1998 )

It is worth to mention that database marketing can be used as a strategy or a tactical approach, if it is considered on the basis of the strategy, these databases can only fit with organization's strategy, and tactic means that it can be removed by consumer groups and analysis of different qualities.

Tactical approach is most appropriate for organizations than strategic approach which is suitable only for organizations that have organized database marketing with a real guide for consumers. (Cooke, 1994)

\section{Quality of Service}

Service quality is of great importance in organizations regardless of the sector in which they operate. To reach the required level of customer satisfaction, it is necessary to focus on improving the level of service quality provided (Hashem, 2018).

Hoffman and Bateson (2011) defined service quality as "a criterion for the degree to which the actual performance of the service matches the expectations of customers or the difference between the expectations of customers and their perception of the actual performance of the service." In this context, Lovelock and Wirtz (2004) it as containing different concepts and meanings according to the difference of customers, and how they perceive the quality of the service provided to them.

Many researchers have stressed the importance of service quality for the success of the organization, as it is necessary to monitor the quality of the service provided and work to measure it according to various scales such as the SERVQUAL scale and the SERVPERF scale (Hashem \& Hamdan ,2017; Ajarmah et al., 2017; Hashem et al., 2018).

\section{Study Significance}

The development in marketing along with great technology development in computer field and data processing, contributed in emergence of databases importance in all the epistemic fields, this importance was applied to database marketing in the various sectors. In spite of the importance of this issue, the studies handled it were limited to the Jordanian environment which lacks such types of studies which can be used to set out a structural base that can help in propounding the understanding of the database marketing in setting out the necessary foundations to use them efficiently in the Jordanian market.

The importance of this study stems from the following:

1- The study will contribute in developing the abilities of using database marketing in improving quality of service in Jordanian private hospitals.

2- The study is conducted in the light of shortage of similar studies in different sectors in Jordan.

\section{The Study's Problem}

The importance of database marketing is increasing day by day regarding building relationships with patients. Despite the importance of improving the quality of the health service in hospitals, it has been noted that there are few previous studies related to the use of marketing databases in order to reach the target health service quality level. It has never been adequately studied before whether the role of database marketing has any influence in improving quality of service in Jordanian private hospitals.

The purpose of this study can be achieved through answering the following questions:

1- What is the role of database marketing in improving quality of service in Jordanian private hospitals? 
2- Is the role of database marketing in improving quality of service in Jordanian private hospitals differ due to variation of (managers' educational level, managers' experience)?

\section{Hypotheses}

First hypothesis: database marketing has an important role in improving quality of service in Jordanian private hospitals.

Second hypothesis: There is no difference of the role of database marketing in improving quality of service in Jordanian private hospitals differ due to variation of managers' educational level.

Third hypothesis: There is no difference in the role of database marketing in improving quality of service in Jordanian private hospitals differ due to variation of managers' experience.

\section{Methodology}

The researcher depended on the experimental methodology, and what follows it of deep analytical field study.

\section{a- Population:}

The study's population is consisted of marketing managers only or their deputies in the Jordanian private hospitals which contains (69) hospitals.

Following equation was used to define the sample size :

$$
\begin{aligned}
& n o=\frac{z^{2} p(1-p)}{e^{2}} \\
& n=\frac{n o N}{n o+(N-1)}
\end{aligned}
$$

no :sample size without corrected factor

Z: confidence level (0.95)

e: sampling error $(0.05)$

$\mathrm{P}$ :probability $(0.5)$

$\mathrm{N}$ :population

$\mathrm{n}$ : sample size with corrected factor

(Berenson \& Levine, 1992, p. 351)

Online questionnaire was distributed over a random sample amounting (59) managers, (51) questionnaires were collected, that is $(86.44 \%)$ of the total sample.

\section{b- Data collection Methods:}

1- Primary Data Collection: an online questionnaire was prepared and distributed over study's sample subjects in order to obtain the primary data necessary for the study.

2- Secondary Data Collection: books, and scientifically resources that are related to the study subject will be used

\section{Questionnaire Design}

An online questionnaire was developed after reviewing the literature review and previous studies from various references, which deal with the research topic.

The ' questionnaire consists of two parts. The first part attempts to collect general information. And the second part consists of all questions related to the objectives and hypothesis of the research.

\section{Validity and Reliability:}

\section{a. Validity:}

The questionnaire has been evaluated by instructors from the Jordanian universities. Their remarks and comments were taken into consideration.

\section{b. Reliability}


Cronbanch Alpha was used to test the reliability of the scale and $\alpha$ was $(0.927)$ for questionnaire which is good because it is greater than accepted percent (0.60). (Malhotra, 2004, p.268)

\section{Characteristics of the Sample:}

Table (2) shows the sample distribution according to the demographic variables. Figures show that the majority $(68.6 \%)$ of the sample is males and only (31.4\%) are females. Moreover, highest observations $(35.3 \%)$ have age Less than 30 years. As far as the educational levels, the table show that (43) observations of the sample (84.3\%) have Bachelor degree. Moreover, highest observations (33.3\%) have age more than 15 years

Table 2. Sample Distribution

\begin{tabular}{|c|c|c|}
\hline Variable & Frequency & $\%$ \\
\hline \multicolumn{3}{|l|}{ Gender: } \\
\hline Male & 35 & 68.6 \\
\hline Female & 16 & 31.4 \\
\hline \multicolumn{3}{|l|}{ Age } \\
\hline Less than 30 years & 18 & 35.3 \\
\hline $30-40$ years & 16 & 31.4 \\
\hline $41-50$ years & 11 & 21.6 \\
\hline More than 50 years & 6 & 11.8 \\
\hline \multicolumn{3}{|l|}{ Education level: } \\
\hline Bachelor (B.A) & 43 & 84.3 \\
\hline High studies & 8 & 15.7 \\
\hline \multicolumn{3}{|l|}{ Experience } \\
\hline Less than 5 years & 15 & 29.4 \\
\hline $5-10$ years & 12 & 23.5 \\
\hline $11-15$ years & 7 & 13.7 \\
\hline More than 15 years & 17 & 33.3 \\
\hline
\end{tabular}

\section{Statistical results:}

Mean and standard deviation were used to describe attitudes toward following questions:

Table 3. descriptive analysis for Role database marketing

\begin{tabular}{|l|l|l|}
\hline \multicolumn{1}{|c|}{ Mean } & STD. Deviation \\
\hline $\begin{array}{l}\text { 1. Staff are trained in the marketing department on the ethics of dealing with } \\
\text { the data stored in databases }\end{array}$ & 3.9216 & 0.93473 \\
\hline $\begin{array}{l}\text { 2. the hospital provides the latest technology to collect patient data, analysis } \\
\text { and use it for patient service }\end{array}$ & 4.0000 & 0.89443 \\
\hline $\begin{array}{l}\text { 3. Teamwork is provided from different departments working effectively } \\
\text { together to take advantage of the data provided by the databases }\end{array}$ & 3.7059 & 0.87850 \\
\hline $\begin{array}{l}\text { 4. the Internet is used in the development of the database marketing in the } \\
\text { hospital }\end{array}$ & 4.2549 & 0.97659 \\
\hline $\begin{array}{l}\text { 5. The data provided by the databases is used in the activation of direct } \\
\text { marketing. }\end{array}$ & 4.0784 & 0.79607 \\
\hline $\begin{array}{l}\text { 6. databases contribute to accuracy in the process of conducting marketing } \\
\text { research }\end{array}$ & 4.0000 & 0.82462 \\
\hline $7 . \quad$ The hospital stores data about patient preferences and product & 3.9608 & 0.89355 \\
\hline 8. Attention is paid to provide full information on all consumer & 3.8824 & 1.01286 \\
\hline $\begin{array}{l}\text { 9. Databases help in the classification of information, including contributing to } \\
\text { the achievement of marketing objectives }\end{array}$ & 3.8039 & 0.84899 \\
\hline 10. technology used in the databases Is adapted with the marketing objectives & 3.6471 & 0.84436 \\
\hline \multicolumn{2}{|l}{} \\
\hline
\end{tabular}

It was found that there are positive attitudes toward questions mentioned in table (3) because their means are above mean of the scale (3), also a quick review of the result in table (3) reveals clearly that variables (4and 5) have the highest mean values in their variables which reflects high degree of positive attitudes toward those questions. 
Table 4. descriptive analysis for service quality

\begin{tabular}{|c|c|c|}
\hline & Mean & STD. Deviation \\
\hline 1. The hospital caters to the various needs of patients & 4.0196 & 0.92715 \\
\hline $\begin{array}{l}\text { 2. There is an interest in improving the quality of the health service } \\
\text { provided }\end{array}$ & 3.9608 & 0.97900 \\
\hline $\begin{array}{l}\text { 3. Changes in the needs and desires of patients are monitored and worked } \\
\text { to satisfy them }\end{array}$ & 3.8431 & 0.88029 \\
\hline 4. Any obstacles to the process of providing health service are avoided & 3.7255 & 0.91823 \\
\hline
\end{tabular}

It was found that there are positive attitudes toward questions mentioned in table (4) because their means are above mean of the scale (3)

\section{Hypothesis Testing:}

First hypothesis: database marketing has an important role in improving quality of service in Jordanian private hospitals.

Table 5. Test of hypothesis (1)

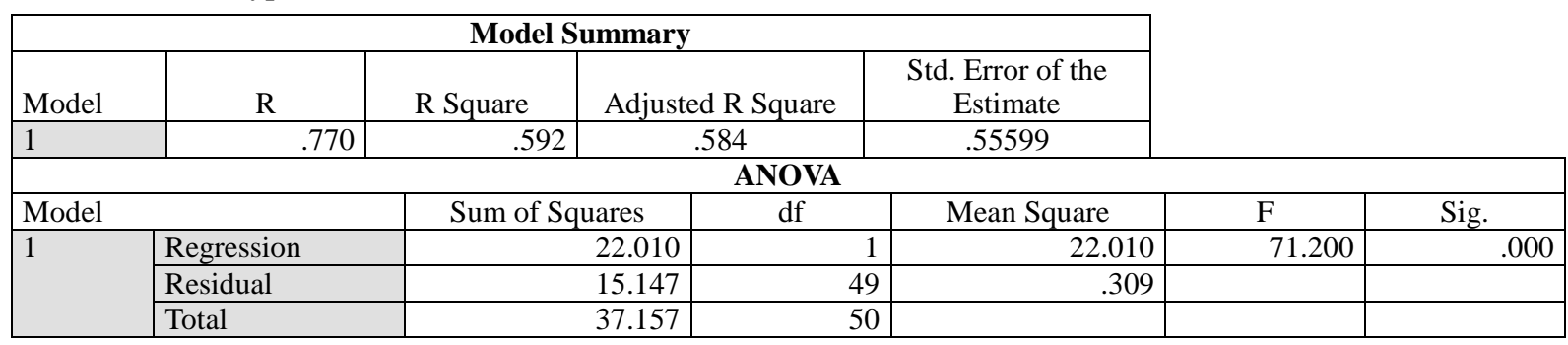

\begin{tabular}{|c|c|c|c|c|c|c|}
\hline \multicolumn{7}{|c|}{ Coefficients } \\
\hline \multirow{2}{*}{\multicolumn{2}{|c|}{ Model }} & \multicolumn{2}{|c|}{ Unstandardized Coefficients } & $\begin{array}{l}\text { Standardized } \\
\text { Coefficients }\end{array}$ & \multirow[b]{2}{*}{$\mathrm{t}$} & \multirow[b]{2}{*}{ Sig. } \\
\hline & & $\mathrm{B}$ & Std. Error & Beta & & \\
\hline 1 & (Constant) & -.835 & 487 & & -1.713 & .093 \\
\hline & DM & 1.017 & .121 & .770 & 8.438 & .000 \\
\hline
\end{tabular}

Linear Regression was used to test above hypothesis and it was found that calculated value of $(t)$ is significant at (0.01) which means that database marketing has an important role in improving quality of service in Jordanian private hospitals. Also, $r=0.77$ reflects high level of relationship between the two variables.

Second hypothesis: There is no difference of the role of database marketing in improving quality of service in Jordanian private hospitals differ due to variation of managers' educational level.

Table 6. Test of hypothesis (2)

\begin{tabular}{|l|r|r|r|r|r|}
\hline \multicolumn{7}{|c|}{ Tests of Between-Subjects Effects } & \\
\hline Source & $\begin{array}{c}\text { Type III Sum of } \\
\text { Squares }\end{array}$ & df & Mean Square & \multicolumn{1}{c|}{ F } & \multicolumn{1}{c|}{ Sig. } \\
\hline Corrected Model & $25.878^{\mathrm{a}}$ & 20 & 1.294 & 3.441 & .001 \\
\hline Intercept & 19.236 & 1 & 19.236 & 51.164 & .000 \\
\hline Education & .198 & 1 & .198 & .526 & .474 \\
\hline DM & 25.391 & 19 & 1.336 & 3.554 & .001 \\
\hline Error & 11.279 & 30 & .376 & & \\
\hline Total & 567.750 & 51 & & & \\
\hline Corrected Total & 37.157 & 50 & & & \\
\hline a. R Squared =.696 (Adjusted R Squared =.494) & \multicolumn{7}{l}{} \\
\hline
\end{tabular}

ANCOVA test was used to test above hypothesis and it was found that calculated value of $(\mathrm{F}=0.526)$ is not significant at (0.05) which means that there is no difference of the role of database marketing in improving quality of service in Jordanian private hospitals differ due to variation of managers' educational level 
Third hypothesis: There is no difference in the role of database marketing in improving quality of service in Jordanian private hospitals differ due to variation of managers' experience.

Table 7. Test of hypothesis (3)

\begin{tabular}{|l|r|r|r|r|r|}
\hline \multicolumn{7}{|c|}{ Tests of Between-Subjects Effects } & & \\
\hline & $\begin{array}{c}\text { Type III Sum of } \\
\text { Squares }\end{array}$ & df & Mean Square & F & \multicolumn{1}{c|}{ Sig. } \\
\hline Source & $25.816^{\mathrm{a}}$ & 20 & 1.291 & 3.415 & .001 \\
\hline Intercept & 30.786 & 1 & 30.786 & 81.439 & .000 \\
\hline Experience & .136 & 1 & .136 & .360 & .553 \\
\hline DM & 23.682 & 19 & 1.246 & 3.297 & .002 \\
\hline Error & 11.341 & 30 & .378 & & \\
\hline Total & 567.750 & 51 & & & \\
\hline Corrected Total & 37.157 & 50 & & & \\
\hline
\end{tabular}

ANCOVA test was used to test above hypothesis and it was found that calculated value of $(\mathrm{F}=0.553)$ is not significant at (0.05) which means that there is no difference of the role of database marketing in improving quality of service in Jordanian private hospitals differ due to variation of managers' experience

\section{Conclusions}

This study aimed to identify the impact of marketing databases on influencing the quality of service provided. It was found that marketing databases are the sum of data related to campaigns and marketing activities from plans, goals and data of customers and consumers that the company uses in managing, coordinating and implementing its marketing campaigns, with the aim of reaching the target audience. and manage the relationship with them. Proceeding from the link between marketing databases and customer and consumer information and data, the link between marketing databases and customer relationship management is a close link in it, given that both areas are concerned with one of the most important assets that contribute to raising the level of marketing performance and increasing its market share, which is "customers". This indicates the importance of maintaining lists of data related to patients and their complete data and its effective role in facilitating the access of marketers and marketing decision-makers to information, in addition to the administrative importance in terms of organization and saving time and effort on the part of marketers and the possibility of accessing feedback from patients in the event of any shortcoming or defect in the service.

Upon the above analysis the following results are concluded:

1) Database marketing has an important role in improving quality of service in Jordanian private hospitals.

2) There is a focus on providing high level of quality of service in Jordanian private hospitals

3) there is no difference of the role of database marketing in improving quality of service in Jordanian private hospitals differ due to variation of managers' experience.

4) there is no difference of the role of database marketing in improving quality of service in Jordanian private hospitals differ due to variation of managers' educational level.

5) The results show the importance of using database marketing in the Jordanian private hospitals

\section{Recommendations}

1) Private hospitals should work to keep up with developments in database marketing field, in the form which enables them to increase efficiency in the use of these rules to improve quality of service

2) Private hospitals should have an Interest in making use of information that is extracted from the database marketing in the design of their marketing strategies.

3) Private hospitals should Work to allocate a separate department regarding the rules of marketing data to increase the benefit from this system to improve the Jordanian Private hospitals, and the 
need to involve the director of this department in the various strategic decisions related to the hospital.

4) Private hospitals should have an attention to the diversification of means of collecting data and information from the surrounding environment and to address weaknesses observed in this area.

5) Training staff is suggested in various departments on how to use database marketing in improving quality of service.

6) A centralized database should be used and where hospitals are providing them with accurate data they need from the surrounding environment.

\section{References}

Ackoff, R. L. (1989). From Data to Wisdom. Journal of Applies Systems Analysis, 16, 3-9.

Ajarmah, B. S., Hashem, T. N., \& Swies, R. J. (2017). The effect of 5Q model on patient's satisfaction in military hospitals in Jordan. Int. J. Productivity and Quality Management, 20(3), 273-290. https://doi.org/10.1504/IJPQM.2017.082634

Bean, R. B. (1997). Business - to - business database marketing: The future in now. (On - line).

Berenson, M., \& Levine, D. (1992). Basic Business statistics- concepts and applications. New Jersey: Prentice Hall.

Brzezinski, C. (1999). Database marketing: Separating, fact from fiction.

Comm., A. (1998). Developing an understanding of the use of marketing databases in Canadian Industry. Master thesis, Carleton University.

Cooke, S. (1994). Database Marketing: Strategy or Tactical Tool, (on-line). https://doi.org/10.1108/02634509410064150

Dawes, J., \& Worthington, S. (1996). Customer Information Systems and Competitive Advantage: a case study of a top ten building society. International Journal of Bank Marketing, (on-line), 14(4). https://doi.org/10.1108/02652329610119300

Ekman, P., Erixon, C., \& Thilenius, P. (2015). Information technology utilization for industrial marketing activities: the IT-marketing gap. Journal of Business \& Industrial Marketing, 30(8), 926-938 . https://doi.org/10.1108/JBIM-01-2014-0014

Eren, E., \& Erdogmus, I. (2004). Knowledge Management and Database Marketing Applications. Dogus Üniversitesi Dergisi, 5(1), 1-16. https://doi.org/10.31671/dogus.2019.302

Friedman, H. H., \& Gildi, K. (2000). Direct Marketing, Database Marketing and Relationship Marketing for the Accounting Practitioner. National Public Accountant, (on-line), 45(3).

Guendhilji, A., \& Janabi, A. (2005). Administrative information systems and information technology. Amman, Al Maseerah house for distribution and printing.

Hamidi, N., Obeid, A., \& al-Samarrai, S. (2004). Management Information Systems. Amman: Dar Wael For Publication.

Hashem, T. (2012). The impact of customer relationship marketing on customers' satisfaction for the banking industry in Jordan. International Journal of Management Cases, 14(4), 142-153. https://doi.org/10.5848/APBJ.2012.00093

Hashem, T. (2016). Commercial Banks Use of Decision Support System to Achieve Marketing Creativity. International Review of Management and Business Research, 5(3), 1059-1067.

Hashem, T. (2018). The Flower of Service Concept and Its Influence on the Customer Satisfaction: Case Study of Jordanian Private Hospitals Sector. International Journal of Business and Management, 13(2), 122-137. https://doi.org/10.5539/ijbm.v13n2p122

Hashem, T., \& Hamdan, F. (2017). Measuring Service Quality Level In The Jordanian Telecommunication Sector From Its Customers' Perspective Using The Servperf Scale. European Journal of Business And Social Sciences, 5(12), 15-27.

Hashem, T., Suleiman, S., Suleiman, A., \& Suleiman, O. (2018). Exploring the Gap between the Perceived and Expected Quality Levels of the Health Care Services Provided by Jordanian Dental Clinics. International Journal of Business and Economic Affairs (IJBEA), 3(2), 64-72. 
https://doi.org/10.24088/IJBEA-2018-32003

Hoffman, K. D., \& Bateson, J. E. G. (2011). Services Marketing, Concepts, Strategies, \& Cases, South- Westeren. Cengage Learning, U.S.A.

Kahan, R. (1998). Using database marketing techniques to enhance your one - to - one marketing initiatives. (on - line). https://doi.org/10.1108/07363769810235965

Kim, M., Eun Park, J., Dubinsky, A., \& Chaiy, S. (2012). Frequency of CRM implementation activities: a customer-centric view. Journal of Services Marketing, 26(2), 83-93 . https://doi.org/10.1108/08876041211215248

Klopp, R. (2000). Database management for marketers ( on line).

Lovelock, C., \& Wirtz, J. (2004). Service Marketing People, Technology, Strategy. United States of America, Hamilton Printing Co, pp.106-107.

Malhotra, N. K. (2004)/ Marketing research. New Jersey: Prentice Hall.

Mckim, B. (2002). The differences between CRM and database marketing. Journal of database Marketing, 9(4). https://doi.org/10.1057/palgrave.jdm.3240086

O'leary, C., Rao, S., \& Perry, C. (2004). Improving Customer Relationship Manager through database/internet marketing: A theory building action research project. European Journal of Information Management, (on-line), 23(4). https://doi.org/10.1108/03090560410518585

Parish, D. A. (1998). Database Marketing. (on -line).

Pokorny, J. (2013). NoSQL databases: a step to database scalability in web environment. International Journal of Web Information Systems, 9(11), 69-82. https://doi.org/10.1108/17440081311316398

Qteishat, M. (2005). DataBases. Amman: Dar Wael For Publication.

Schoenbachler, D., Gordon, G., Foley, D., \& Spellman, L. (1997). Understanding consumer database marketing. Journal of consumer marketing, 14(1), 5-19. https://doi.org/10.1108/07363769710155820

Singh, J., \& Saini, S. (2016). Importance of CEM in CRM-CL framework. Journal of Modelling in Management, 11(1), 91-115 .https://doi.org/10.1108/JM2-05-2014-0038

Strubel, M. (2000). Database Marketing and Management (on-line).

Tapp, A. (2005). Principles of direct and database marketing. New jersey: Prentice Hall.

Yassin, S. (2005). Analysis and Design of Information Systems. Amman: Dar Al- Manahij for publication and distribution.

\section{Copyrights}

Copyright for this article is retained by the author(s), with first publication rights granted to the journal.

This is an open-access article distributed under the terms and conditions of the Creative Commons Attribution license (http://creativecommons.org/licenses/by/4.0/). 